\title{
A study on the preparation and characterization of plasmid DNA and drug-containing magnetic nanoliposomes for the treatment of tumors
}

This article was published in the following Dove Press journal:

International Journal of Nanomedicine

26 April 201 I

Number of times this article has been viewed

\author{
Zi-Yu Wang ${ }^{1,2}$ \\ Li Wang' \\ Jia Zhang' \\ Yun-Tao Li' \\ Dong-Sheng Zhang' \\ 'School of Medicine, \\ Southeast University, Nanjing, China; \\ ${ }^{2}$ School of Basic Medical Sciences, \\ Nanjing University of Traditional \\ Chinese Medicine, Nanjing, China
}

Correspondence: Dong-Sheng Zhang School of Medicine, Southeast University, Nanjing 210009, China

Tel +86 2583272502

Fax +86 25 577I 2900

Email b7712900@jlonline.com
Purpose: To explore the preparation and characterization of a novel nanosized magnetic liposome containing the PEI- $\mathrm{As}_{2} \mathrm{O}_{3} / \mathrm{Mn}_{0.5} \mathrm{Zn}_{0.5} \mathrm{Fe}_{2} \mathrm{O}_{4}$ complex.

Methods: $\mathrm{Mn}_{0.5} \mathrm{Zn}_{0.5} \mathrm{Fe}_{2} \mathrm{O}_{4}$ and $\mathrm{As}_{2} \mathrm{O}_{3} / \mathrm{Mn}_{0.5} \mathrm{Zn}_{0.5} \mathrm{Fe}_{2} \mathrm{O}_{4}$ nanoparticles were prepared by chemical coprecipitation and loaded with PEI. The PEI- $\mathrm{As}_{2} \mathrm{O}_{3} / \mathrm{Mn}_{0.5} \mathrm{Zn}_{0.5} \mathrm{Fe}_{2} \mathrm{O}_{4}$ complex was characterized using transmission electron and scanning electron microscopy, X-ray diffraction, energy dispersive spectrometry, and Fourier transform infrared spectroscopy. Cell transfection experiments were performed to evaluate the transfect efficiency. Magnetic nanoliposomes were prepared by rotatory evaporation and their shape, diameter, and thermodynamic characteristics were observed.

Results: $\mathrm{Mn}_{0.5} \mathrm{Zn}_{0.5} \mathrm{Fe}_{2} \mathrm{O}_{4}$ and $\mathrm{PEI}-\mathrm{As}_{2} \mathrm{O}_{3} / \mathrm{Mn}_{0.5} \mathrm{Zn}_{0.5} \mathrm{Fe}_{2} \mathrm{O}_{4}$ nanoparticles were spherical, with an average diameter of 20-40 nm. PEI- $\mathrm{As}_{2} \mathrm{O}_{3} / \mathrm{Mn}_{0.5} \mathrm{Zn}_{0.5} \mathrm{Fe}_{2} \mathrm{O}_{4}$ was an appropriate carrier for the delivery of a foreign gene to HepG2 cells. Energy dispersive spectrometry results confirmed the presence of the elements nitrogen and arsenic. Nanoliposomes of approximately $100 \mathrm{~nm}$ were observed under a transmission electron microscope. Upon exposure to an alternating magnetic field, they also had good magnetic responsiveness, even though $\mathrm{Mn}_{0.5} \mathrm{Zn}_{0.5} \mathrm{Fe}_{2} \mathrm{O}_{4}$ was modified by PEI and encased in liposomes. Temperatures increased to $37^{\circ} \mathrm{C}-54^{\circ} \mathrm{C}$ depending on different concentrations of $\mathrm{PEI}-\mathrm{As}_{2} \mathrm{O}_{3} / \mathrm{Mn}_{0.5} \mathrm{Zn}_{0.5} \mathrm{Fe}_{2} \mathrm{O}_{4}$ and remained stable thereafter.

Conclusion: Our results suggest that $\mathrm{PEI}-\mathrm{As}_{2} \mathrm{O}_{3} / \mathrm{Mn}_{0.5} \mathrm{Zn}_{0.5} \mathrm{Fe}_{2} \mathrm{O}_{4}$ magnetic nanoliposomes are an excellent biomaterial, which has multiple benefits in tumor thermotherapy, gene therapy, and chemotherapy.

Keywords: nanoliposomes, magnetic fluid hyperthermia, $\mathrm{As}_{2} \mathrm{O}_{3}$, DNA

\section{Introduction}

Completion of the human genome project has greatly increased the discovery of functional and disease-related genes. Gene therapy has become one of the most active research areas in biomedicine in the 21 st century. One of the main advantages of gene therapy over traditional therapy is the potential to target the expression of therapeutic genes in desired cells or tissues. To achieve targeted gene expression, we developed a novel nonviral gene delivery system.

Arsenic trioxide $\left(\mathrm{As}_{2} \mathrm{O}_{3}\right)$ has been adopted from traditional Chinese medicine and used successfully to treat refractory or relapsed acute promyelocytic leukemia. ${ }^{1}$ In recent years, some researchers have found that $\mathrm{As}_{2} \mathrm{O}_{3}$ was not only effective in leukemia treatment, but also effective in inhibiting several animal and human solid cancers, such as neuroblastoma, liver, and gastric cancers. ${ }^{2-4}$ However, there is a lack of drug specificity with the intravenous or oral administration of $\mathrm{As}_{2} \mathrm{O}_{3}$, resulting in the requirement 
of large doses to achieve high local concentrations. This can cause nonspecific toxicity and other adverse side effects. Moreover, $\mathrm{As}_{2} \mathrm{O}_{3}$ has been generally considered to be an extremely effective environmental cocarcinogen for some human malignancies, especially for renal, skin, and lung cancer. ${ }^{5-7}$ Therefore, we investigated an alternative means of administering $\mathrm{As}_{2} \mathrm{O}_{3}$ to enhance its curative effects and reduce toxicity.

Clinically, the use of thermotherapy, such as heating certain organs or tissues to temperatures between $41^{\circ} \mathrm{C}$ and $46^{\circ} \mathrm{C}$, also known as hyperthermia, has been longused in the treatment of tumors. With the development of nanotechnology, magnetic nanoparticles have been used for tumor hyperthermia, to absorb energy from an applied high frequency alternating magnetic field (AMF). This treatment is known as magnetic fluid hyperthermia $(\mathrm{MFH}){ }^{8}$ $\mathrm{MFH}$ is more effective in the uniform heating of deeplysituated tumors, with relatively good targeting. Generally, in this technique, magnetic fluids are dispersed into the target tissue, which are then heated through the application of an external AMF. ${ }^{9}$

In this paper, we aimed to develop a novel nanosized magnetic liposome containing the PEI-As $\mathrm{O}_{3} / \mathrm{Mn}_{0.5} \mathrm{Zn}_{0.5} \mathrm{Fe}_{2} \mathrm{O}_{4}$ (PEI-As $\left.{ }_{2} \mathrm{O}_{3} / \mathrm{MZF}\right)$ complex. Herein we also show multiple antitumor functions, including thermotherapy of magnetic MZF nanoparticles, gene therapy of PEI-modified complexes, and chemotherapy using $\mathrm{As}_{2} \mathrm{O}_{3}$. With further research, it may develop into a new approach for the treatment of tumors.

\section{Experimental details}

\section{Main reagents and cell line}

$\mathrm{As}_{2} \mathrm{O}_{3}$ (Sigma Aldrich, St Louis, MO); PEI (Sigma Aldrich); phosphatidyl choline (Lipoid LLC, Newark, NY); cholesterol (Sigma Aldrich); human liver cancer HepG2 cell lines were provided by the Institute of Biochemistry and Cell Biology, Shanghai Institute of Biological Science, Chinese Academy of Sciences, China.

\section{Methods}

\section{Preparation of MZF and $\mathrm{PEI}-\mathrm{As}_{2} \mathrm{O}_{3} I$}

\section{MZF nanoparticles}

MZF nanoparticles were prepared using chemical coprecipitation. They were examined by transmission electron microscopy (TEM) (H-600; Hitachi, Tokyo, Japan) and scanning electron microscopy (SEM) (JSM-6360LV; Jeol, Tokyo, Japan). The element composition and content of the nanoparticles were analyzed by X-ray diffraction (XRD) and energy dispersive spectrometry (EDS) (Vantage; Thermo
Noran, Middleton, WI). MZF was subsequently modified by $\mathrm{As}_{2} \mathrm{O}_{3}$ and adsorbed by PEI, according to a previouslydescribed method. The adsorption efficiency of PEI was demonstrated by Fourier transform infrared spectroscopy (FTIR) (560; Thermo Nicolet, Madison, WI) and EDS.

\section{Cell transfection}

Prior to transfection, pGFP plasmid DNA and PEI-As $\mathrm{O}_{3} /$ MZF nanoparticles were diluted separately in serum- and supplement-free medium. Subsequently, $6 \mu \mathrm{g}$ plasmid DNA per well was complexed with various amounts of PEI$\mathrm{As}_{2} \mathrm{O}_{3} / \mathrm{MZF}-\mathrm{NPs}(10 \mathrm{mg} / \mathrm{mL})$, corresponding to a nitrogen/ phosphorus $(\mathrm{N} / \mathrm{P})$ ratio of particles to DNA in a final volume of $400 \mu \mathrm{L}$ serum- and supplement-free medium. The complexes were then incubated at room temperature for 30 minutes. As a reference, ${ }^{10}$ PEI (complexed with DNA at an N/P ratio of 7) or commercially-available transfection reagents, such as Lipofectamine ${ }^{\mathrm{TM}}$ (Invitrogen, Carlsbad, CA) were used in accordance with the manufacturer's instructions.

HepG-2 cells were seeded in six well plates, at an initial density of $2 \times 10^{5}$ cells/well in $2 \mathrm{~mL}$ growth medium. After incubation for 18 hours, when cells had reached $80 \%$ confluency, the medium was replaced with $1.6 \mathrm{~mL}$ serum-free media and $400 \mu \mathrm{L}$ PEI-As ${ }_{2} \mathrm{O}_{3} / \mathrm{MZF}-\mathrm{NPs} /$ pGFP complexes, followed by a further incubation for 4 hours. The medium was then exchanged for fresh medium containing serum

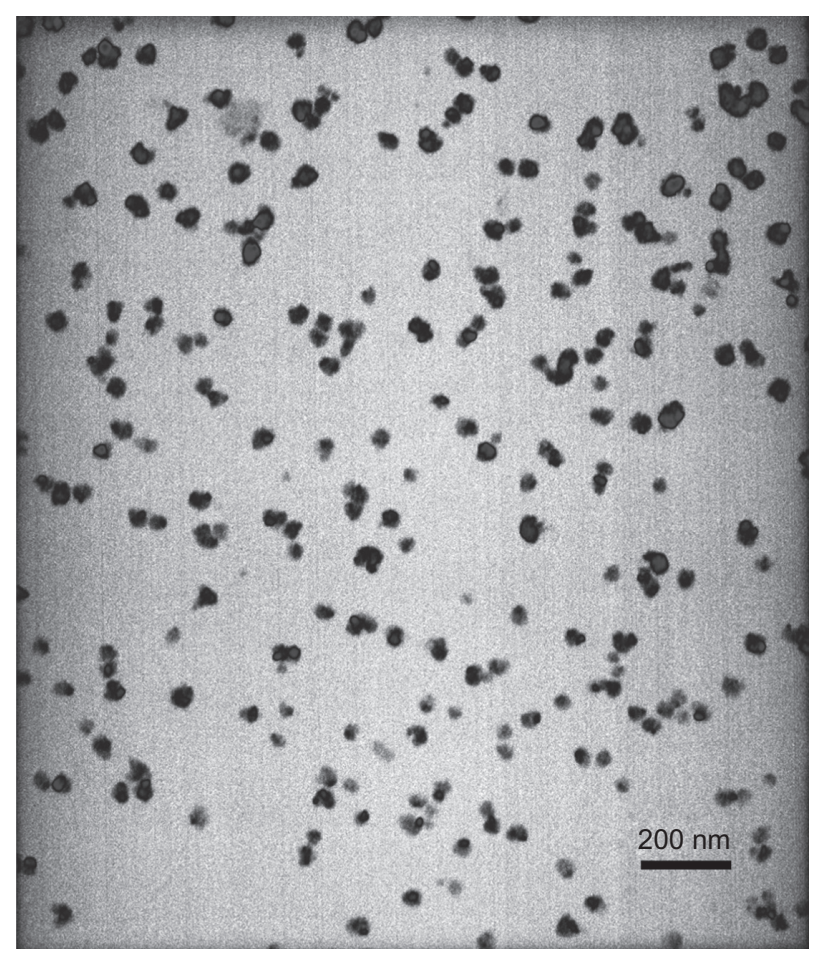

Figure I TEM image of $\mathrm{Mn}_{0.5} \mathrm{Zn}_{0.5} \mathrm{Fe}_{2} \mathrm{O}_{4}$ nanoparticles. 
A

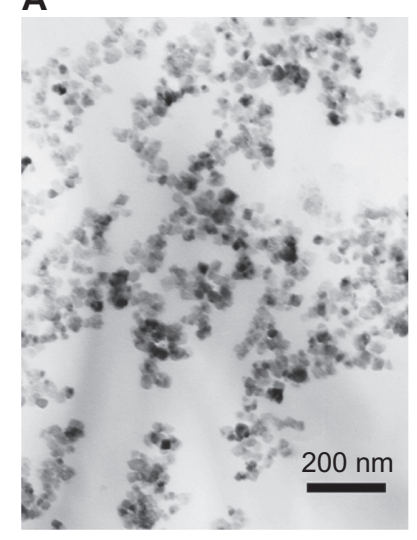

B

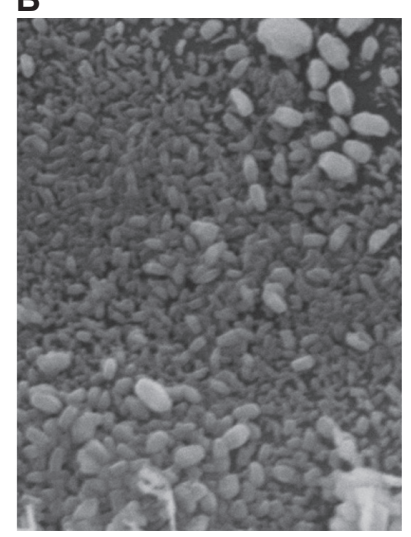

Figure $2 \mathrm{PEI}-\mathrm{As}_{2} \mathrm{O}_{3} / \mathrm{MZF}$ as seen by TEM (A) and SEM (B).

Abbreviations: $\mathrm{PEI}$, polyethyleneimine; TEM, transmission electron microscopy; SEM, scanning electron microscopy.

and incubated further. Cells were observed using inverted fluorescence microscopy at 24 hours and 48 hours posttransfection, to evaluate transfection efficiency.

\section{Preparation of nanoliposomes, containing} $\mathrm{PEI}-\mathrm{As}_{2} \mathrm{O}_{3} / \mathrm{MZF}$ and heating tests

Magnetic nanoliposomes were obtained by the combined methods of rotatory film and high-pressure homogenization. A heat test was performed to detect the thermodynamic

characteristics of the magnetic nanoliposomes. Various doses of nanoliposomes were decentralized in $0.9 \%$ sodium chloride, with concentrations of $\mathrm{PEI}-\mathrm{As}_{2} \mathrm{O}_{3} / \mathrm{MZF}$ as follows: $5,10,15,20,30 \mathrm{~g} / \mathrm{L}$. The output electric current was $300 \mathrm{~A}$ and the fluid was heated for 1 hour with temperature measurements every 5 minutes.

\section{Results and discussion}

\section{Characterization of MZF and PEI-As $\mathrm{O}_{3} /$ MZF nanoparticles}

MZF nanoparticles were evaluated by TEM, XRD, and EDS. Using TEM, MZF particles appeared round or elliptical in shape, with good dispersion and were $20-30 \mathrm{~nm}$ in diameter (Figure 1). These nanoparticles were identified as $\mathrm{Mn}_{0.5} \mathrm{Zn}_{0.5} \mathrm{Fe}_{2} \mathrm{O}_{4}$ by XRD and EDS.

Figures $2 \mathrm{~A}$ and $2 \mathrm{~B}$ show PEI-As $\mathrm{O}_{3} / \mathrm{MZF}$ nanoparticles under TEM and SEM. The nanoparticles were brown spherical particles, with diameters ranging from 30 to $40 \mathrm{~nm}$. Furthermore, they suspended stably in water, with good diffusibility. FTIR showed specific peaks at $1,471 \mathrm{~cm}^{-1}$, $2,826 \mathrm{~cm}^{-1}$, and $2,954 \mathrm{~cm}^{-1}$, as compared to $\mathrm{As}_{2} \mathrm{O}_{3} / \mathrm{MZF}$ complexes (Figure 3). The EDS results verified the presence of the elements manganese, zinc, iron, arsenic, and

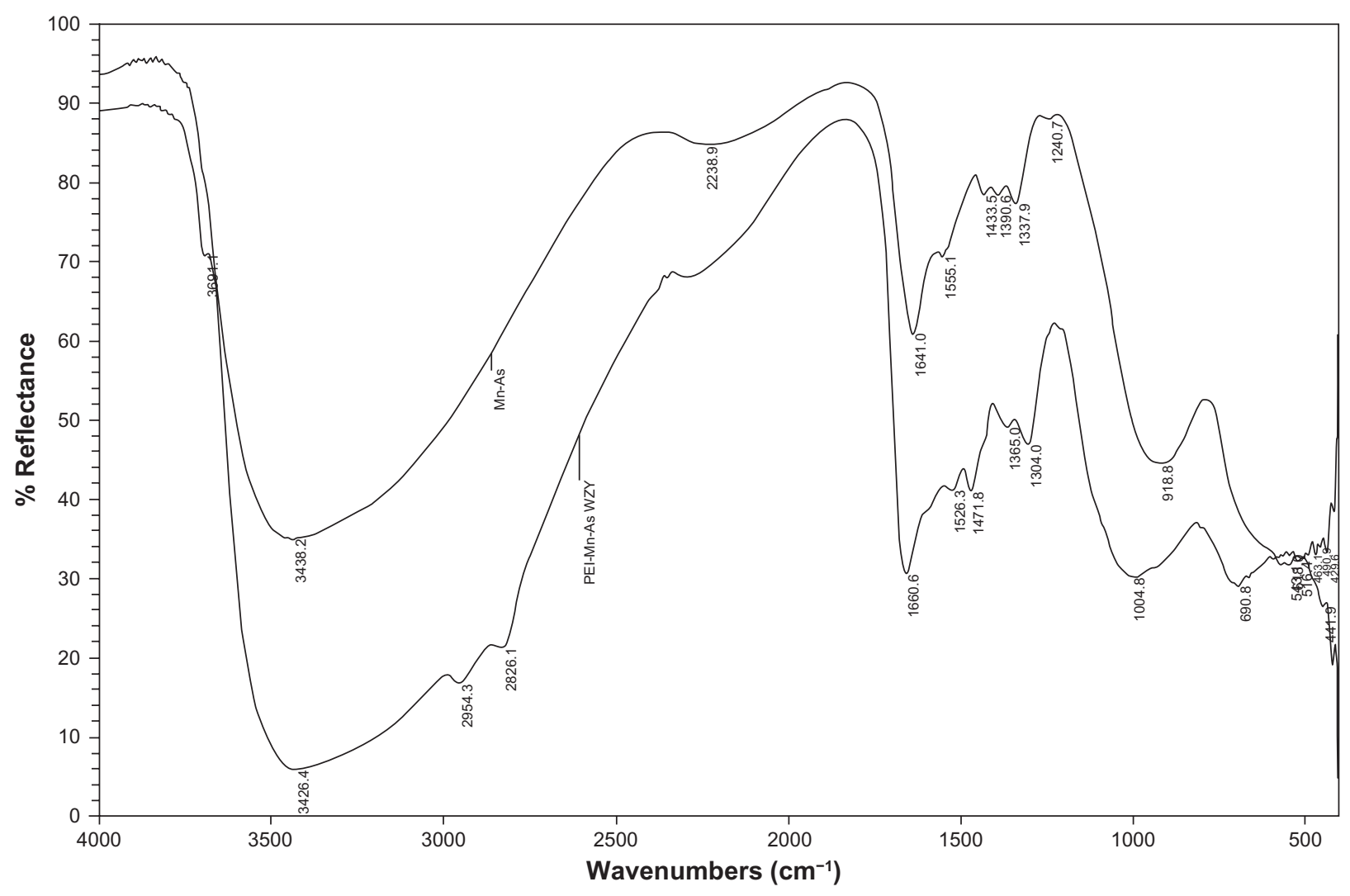

Figure 3 FTIR of PEI-As $\mathrm{O}_{3} / \mathrm{MZF}$ : the top curve is $\mathrm{As}_{2} \mathrm{O}_{3} / \mathrm{MZF}$ and the bottom is $\mathrm{PEI}-\mathrm{As}_{2} \mathrm{O}_{3} / \mathrm{MZF}$. Abbreviations: FTIR, Fourier transform infrared spectroscopy; $\mathrm{PEI}$, polyethyleneimine. 


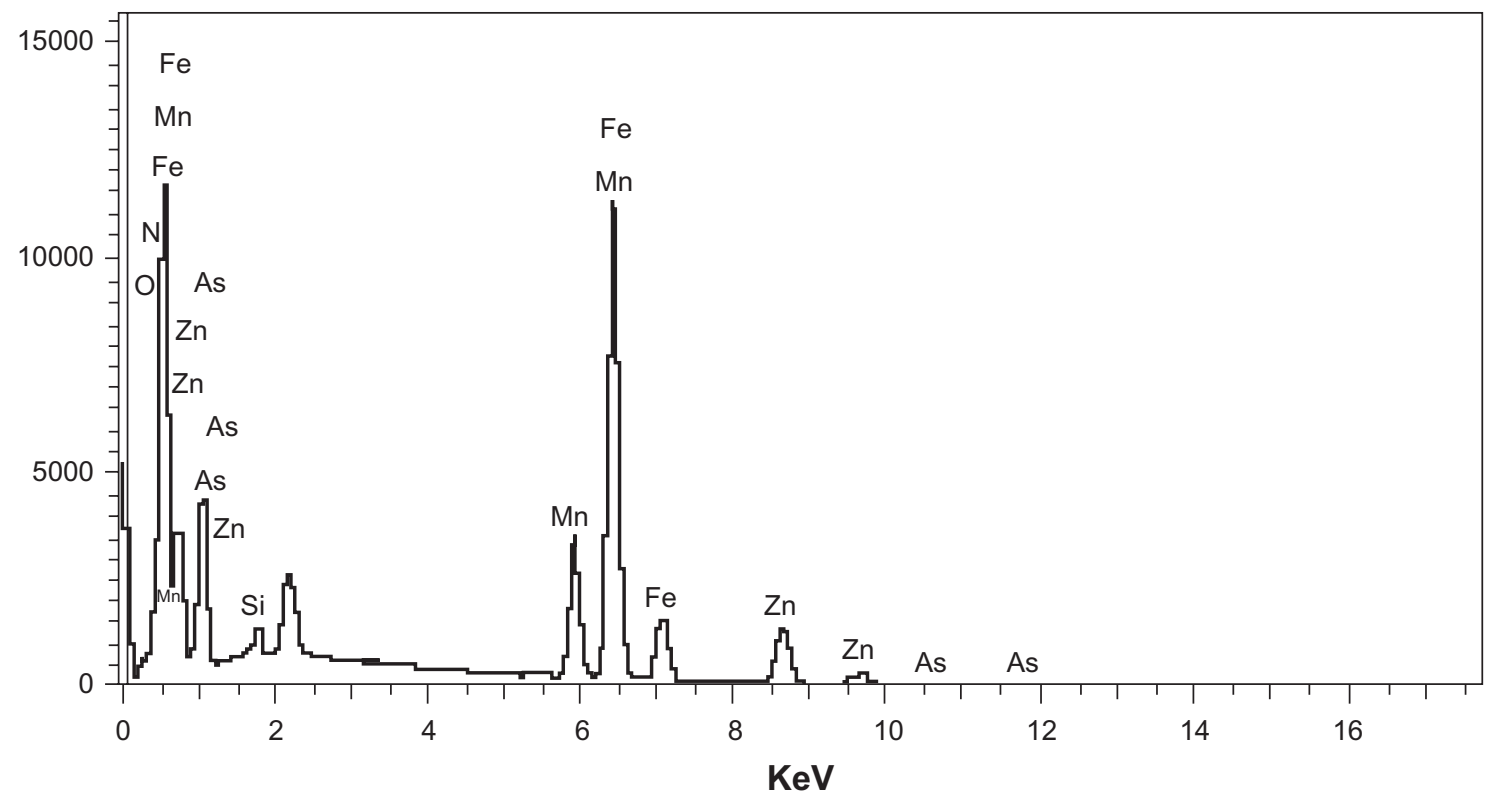

Figure 4 EDS results of $\mathrm{PEI}-\mathrm{As}_{2} \mathrm{O}_{3} / \mathrm{MZF}$.

Abbreviations: EDS, energy dispersive spectrometry.

nitrogen (Figure 4). Further cell transfection experiments suggested that $\mathrm{PEI}-\mathrm{As}_{2} \mathrm{O}_{3} / \mathrm{MZF}$ nanoparticles were efficient carriers for gene transfection. The observed green cellular fluorescence was due to pGFP expression, which was confirmed by inverted fluorescence microscopy 24 hours post-transfection. The expression of GFP was much clearer at 48 hours post-transfection (Figure 5). This high transfer efficiency was due to the inherent proton absorption properties of PEI. ${ }^{11}$ However, the use of PEI as a gene carrier is limited by cytotoxicity and nonspecific interactions with serum proteins. In our study, we used nanoliposomes to engulf the PEI- $\mathrm{As}_{2} \mathrm{O}_{3} / \mathrm{MZF}$ complexes and reduce their toxic side effects, which has not been previously reported.

\section{Properties of nanoliposomes containing $\mathrm{PEI}-\mathrm{As}_{2} \mathrm{O}_{3} / \mathrm{MZF}$}

We prepared magnetic nanoliposomes containing PEI$\mathrm{As}_{2} \mathrm{O}_{3} / \mathrm{MZF}$ complexes, with an average diameter of
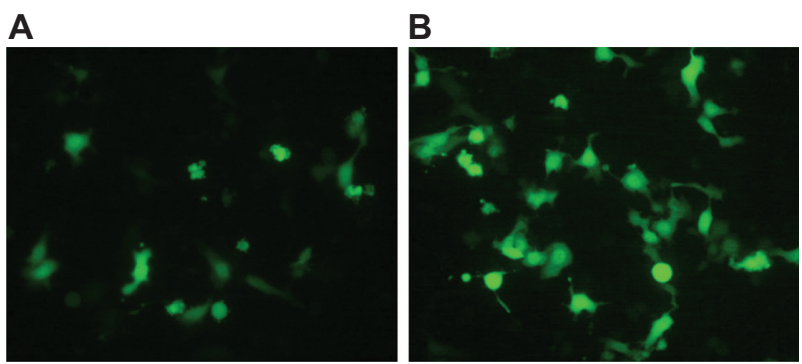

Figure 5 HepG2 cells observed under fluorescence microscopy $(\times 400) 24$ hours after transfection (A) and 48 hours after transfection (B). approximately $100 \mathrm{~nm}$. The encapsulation ratio of $\mathrm{As}_{2} \mathrm{O}_{3}$ was analyzed by fluorescence spectrophotometry and determined to be $75.33 \%$. An in vitro heating test was performed to detect the thermodynamic characteristics of the nanoliposomes. The temperature of the nanoliposomes exposed to AMF rose rapidly within the first 5 minutes and slowly continued to increase from 5-40 minutes, remaining stable thereafter. The temperature rose from $37^{\circ} \mathrm{C}$ to $54^{\circ} \mathrm{C}$, depending on various doses of PEI-As $\mathrm{O}_{3} / \mathrm{MZF}$ (Figure 6). The results showed that nanoliposomes had good absorption properties in high-frequency alternating electromagnetic fields, due to the presence of magnetic nanoparticles. The modified PEI, $\mathrm{As}_{2} \mathrm{O}_{3}$, and lipid membrane did not influence the magnetic responsiveness of MZF. Therefore, we can select a suitable temperature range $\left(42^{\circ} \mathrm{C}-46^{\circ} \mathrm{C}\right)$ for tumor hyperthermia by adjusting the concentration of $\mathrm{PEI}-\mathrm{As}_{2} \mathrm{O}_{3} / \mathrm{MZF}$.

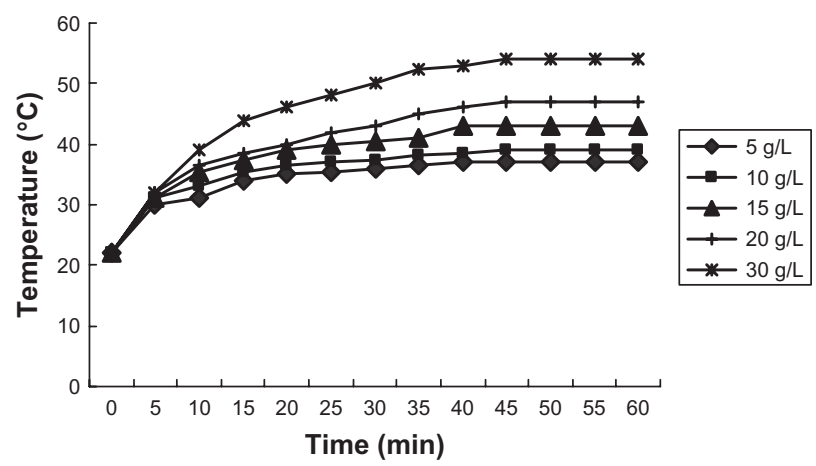

Figure 6 Heating test result of magnetic nanoliposomes. 


\section{Conclusion}

Nanotechnology has been increasingly applied in the medical field, with potential treatments for cancer. In our study, we prepared a new kind of magnetic nanoliposome containing PEI-As $\mathrm{O}_{3} / \mathrm{MZF}$ complexes. It has multiple antitumor applications, including thermotherapy using magnetic MZF nanoparticles, gene therapy with PEI-modified complexes, and chemotherapy using $\mathrm{As}_{2} \mathrm{O}_{3}$. In future studies, we will apply this novel material to tumor therapy.

\section{Acknowledgments}

This work was supported by the Chinese National 863 Plan (No: 2007 AA03Z356), and the Chinese National Natural Science Foundation (No: 30770584).

\section{Disclosure}

The authors declare no conflicts of interest with respect to the authorship and/or publication of this article.

\section{References}

1. Jing Y, Xia L, Waxman S. Targeted removal of PML-RARalpha protein is required prior to inhibition of histone deacetylase for overcoming all-trans retinoic acid differentiation resistance in acute promyelocytic leukemia. Blood. 2002;100(3):1008-1013.
2. Luo L, Qiao H, Meng F, et al. Arsenic trioxide synergizes with B7H3-mediated immunotherapy to eradicate hepatocellular carcinomas. Int $J$ Cancer. 2006;118(7):1823-1830.

3. Florea AM, Splettstoesser F, Busselberg D. Arsenic trioxide (As2O3) induced calcium signals and cytotoxicity in two human cell lines: SY-5Y neuroblastoma and 293 embryonic kidney (HEK). Toxicol Appl Pharmacol. 2007;220(3):292-301.

4. Xiao YF, Wu DD, Liu SX, Chen X, Ren LF. Effect of arsenic trioxide on vascular endothelial cell proliferation and expression of vascular endothelial growth factor receptors Flt-1 and KDR in gastric cancer in nude mice. World J Gastroenterol. 2007;13(48):6498-6505.

5. Zhao X, Feng T, Chen H, et al. Arsenic trioxide-induced apoptosis in $\mathrm{H} 9 \mathrm{c} 2$ cardiomyocytes: implications in cardiotoxicity. Basic Clin Pharmacol Toxicol. 2008;102(5):419-425.

6. Li Z, Piao F, Liu S, et al. Preventive effects of taurine and vitamin C on renal DNA damage of mice exposed to arsenic. J Occup Health. 2009;51(2):169-172.

7. Patrick L. Toxic metals and antioxidants: Part II. The role of antioxidants in arsenic and cadmium toxicity. Altern Med Rev. 2003;8(2): $106-128$.

8. Jordan A, Wust P, Scholz R, et al. Cellular uptake of magnetic fluid particles and their effects on human adenocarcinoma cells exposed to AC magnetic fields in vitro. Int J Hyperthermia. 1996;12(6):705-722.

9. Tasci TO, Vargel I, Arat A, Guzel E, Korkusuz P, Atalar E. Focused RF hyperthermia using magnetic fluids. Med Phys. 2009;36(5): 1906-1912.

10. Tang QS, Zhang DS, Cong XM, Wan ML, Jin LQ. Using thermal energy produced by irradiation of $\mathrm{Mn}-\mathrm{Zn}$ ferrite magnetic nanoparticles (MZF-NPs) for heat-inducible gene expression. Biomaterials. 2008; 29(17):2673-2679.

11. Pathak A, Vyas SP, Gupta KC. Nano-vectors for efficient liver specific gene transfer. Int J Nanomedicine. 2008;3(1):31-49.
International Journal of Nanomedicine

\section{Publish your work in this journal}

The International Journal of Nanomedicine is an international, peerreviewed journal focusing on the application of nanotechnology in diagnostics, therapeutics, and drug delivery systems throughout the biomedical field. This journal is indexed on PubMed Central,

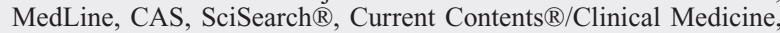

\section{Dovepress}

Journal Citation Reports/Science Edition, EMBase, Scopus and the Elsevier Bibliographic databases. The manuscript management system is completely online and includes a very quick and fair peer-review system, which is all easy to use. Visit http://www.dovepress.com/ testimonials.php to read real quotes from published authors. 